\title{
PAULO ORÓSIO E O PROVIDENCIALISMO NO MARCO DO IMIPÉRIO ROMANO
}

Maria Sonsoles Guerras

UFRJ

Abstract

This work makes part of the collective research of some professors and students of the History Department - Sector of Ancient and Medieval History - of UFRJ, who are financed by CNPq.

After making a brief biographical sketch of Paulo Orósio, contemporary of Agostinho from Hipona, we analise the traces of the classical roman culture that can be found in his work: the authors who served as sources for him, Cicero's doctrine of classic historiography that he follows, and so on.

The second part contains an analysis of some facts from roman history which are, in the point of view of the author of the "Seven Books of History", a clear demonstration of how Providence has made use of the Roman World to start a new era: Chist is born during August's time, therefore these two events will be forever joint and the "Pax Romana" will be the very beginning of the "Pax Chrlsti".

The objective of work is the analysis of Paulo Orosio's historical providentlalism, for whom the Roman Emplre is God's instrument for getting to the real Universal Chistian Empire, according to Daniel's prophecy. 
Este trabalho es parte inntegrante da pesquisa realizada por professores, alunos e alguns ex-alunos, bolsistas do CNPq, do Departamento de História do IFCS da UFRJ. A pesquisa, aprovada $\theta$ financiada pelo $\mathrm{CNPq}$, centraliza-se na releitura da historiografia pagă e cristå da Antigüidade Tardia.

O objetivo especffico desta comunicaçáo é apresentar parte do trabalho, já realizado, porém ainda náo concluldo, sobre Paulo Orósio. Qual o grau de consciência que ele possui frente ao acontecer histórico por ele vivenciado? É contemporâneo do "saque de Roma", de 410, por Alarico e sofre diretamente, como hispano, as consequências da irrupçăo dos germanos na Península lbérica. Qual a sua visăo do Império no inicio do século $V$ ? Na qualidade de historiador cristão, como ele analisa o contexto?

Pouco sabemos da vida de Paulo Orósio: o que ele mesmo nos transmite em sua obra Os Sete Livros de História contra os Pagáos e as not'cias contidas em duas cartas de Santo Agostinho e uma carta de São Jerónimo.

Com relação ao lugar de nascimento há duas opiniōes. Para uns seria Tarragona, cidade ibérica, à margem do Mediterrâneo. O fundamento para sustentar esta tese encontra-se nas palavras do próprio autor, quando na sua obra diz: "nossa Tarragona"1. Para outros autores teria nascido em Braga, no litoral do Attântico. As duas cartas de Santo Agostinho viriam em confirmação desta hipótese. Numa delas diz: "Chegou até mim desde o litoral do Oceano..." e na outra: "Chegou até mim desde o extremo de Hispånia, isto é, desde o litoral do Oceano..."2.

Outro ponto obscuro é a data do nascimento. Santo Agostinho afirma na carta a Săo Jerónimo, no inf́cio do ano 415, referindo-se a Orósio: “... é jovem,... e filho pela idade". A palavra jovem encontra-se duas vezes no mesmo parágrafo. Igual expressão encontramos na carta pelo próprio São Agostinho, ao bispo Evódio, nos fins do mesmo ano de 415.

As cartas de Santo Agostinho, a que estamos fazendo referência, aludem, também, à estada de Paulo Orósio na África - junto ao bispo de Hipona - e até a uma viagem ao Oriente para encontrar-se com Săo Jerónimo, a pedido do próprio Agostinho. Os motivos nấo de todo explícitos como desejarfamos, os encontramos igualmente nas mesmas fontes. "Chegou até aqui Orósio ... quer combater as falsas e perniciosas doutrinas que assassinam as almas dos espanhois com mais rigor que tombam seus corpos com a espada dos bárbaros ... Veio até mim esperando ouvir-me expor alguns pontos que deseja conhecer. Exortei-o a ir ao encontro de (Jeronimo) e ele recebeu com gosto meu conselho ou preceito ..." ${ }^{\text {"3 }}$. Na carta escrita ao bispo Evódio, encontramos a mesma idéia: "... (Orósio) veio até mim movido tåo somente pelo desejo de conhecer as Santas Escrituras. Este Orósio me fez algumas perguntas que o inquietavam sobre a heresia dos priscilianistas ..." Na carta de Săo Jerônimo, dirigida a Santo Agostinho, encontramos a confirmaçăo da viagem ao Oriente: "Recebi, como ele merece e tu me pedias, o presbftero Orósio..." 4 .

\footnotetext{
1 -Orósio, 1982: v. 2, 216.

2 - (1953:4655.529).

$3-(1953: 465.529)$.

$4-(1962: 756)$.
} 
Se a leitura destes textos nos leva a crer que a viagem à Átrica teve motivos religiosos $\theta$ intelectuais, por outro lado, o próprio Paulo Orósio nos oferece uma versáo diferente nas suas Histórias contra os Pagáos: "... quando falo de mim mesmo, por exemplo, que em um primeiro momento me vi frente aos bárbaros aos quals nunca vira antes [...] que os burlei quando me retinham $e$, finalmente que deles escapel, coberto por uma súbita neblina, quando me perseguiam pelo mar ..." A mesma idéla se repete depois: "Eu que aproveito para fugir à primeira pertubaçăo de uma situaçăo turbulenta, seja do tipo que for ....5. Diante da leitura das duas versóes, torna-se diffcil saber qual foi a verdadeira causa da viagem.

$\mathrm{Na}$ África, a pedido de Santo Agostinho, redige sua grande obra Os Sete Livros de História contra os Pagáos. O fato do livro ter sido escrito a pedido do bispo de Hipona está explicitado várias vezes na própria obra. Por exemplo, no prólogo, encontramos seu testemunho pessoal com estas palavras: "Obedeci aos teus mandatos; bem-aventurado pai Agostinho. Ordenaste-me que escrevesse contra a vã maldade daqueles que, alheios à Cidade de Deus, săo chamados pagãos ..., ordenaste-me que de todos os registros de histórias e anais que possam ser encontrados no momento presente, expusesse em capftulos breves e sistemáticos de um livro, tudo o que eu tivesse encontrado ..."

No fim do livro VII estão escritas estas palavras: "De acordo com o teu mandato, bem-aventurado pai Agostinho, mostrei o que aconteceu desde o começo do mundo até os nossos dias. Da qualidade da obra, tu que a ordenastes, julgarás; cabe a ti decidir se a publicas ou destróis" 6 .

Depois de escrita a obra, após sua viagem à África $\theta$ ao Oriente, novamente perdemos de vista Paulo Orósio e mais nada sabemos de sua vida.

Os traços de sua personalidade ficaram gravados na correspondência de Santo Agostinho: "... (Orósio) jovem piedoso, irmåo na paz católica, filho por idade e copresbltero por dignidade, aberto de engenho, fácil de palavra, forte nos desejos, aspira a ser útil na casa de Deus. Já colheu alguns frutos de sua viagem, ... ensine! quando me foi possivel e, quando não pude, mostrei-lhe como aprender. Estava eu procurando a quem consultar e náo encontrava, facilmente, um sujeito idóneo por sua fidelidade em negociar, pressa em obedecer e prática de peregrinar. Logo que conheci este jovem. não fol mais possivel duvidar de que era tal qual eu o pedia a Deus". De "... jovem presbftero, santo e estudioso ..." é chamado pelo mesmo Agostinho quando escreve ao bispo Evódio. Săo Jerônimo, respondendo a Agostinho, expressa os mesmos sentimentos: "Recebl ... o presbftero Orósio, varăo digno de toda honra"я.

Dos Sete Livros de Historia contra os Pagåos temos duzentos e quarenta $\theta$ cinco manușcritos. As primeiras ediçбos da obra săo dos fins do século XV. Encontra-

5 (1982: v. 1, 236; v.2, 15).

6 - (ltid.: v. 1, 78; v.2, 281).

$7 \quad(1953: 465.529)$.

$8 \quad 119(i ; \cdot / 5,6)$. 
mos, igualmente, ediçóes nos séculos XVI e XVII. Depois năo há ediçôs até o século $X X$. As traduçőes săo bem mais antigas: a primeira foi feita no século IX por ordem do rei anglo-saxăo Alfredo. No século $X$ a obra foi traduzida para $o$ árabe encontrando-se $o$ único exemplar existente na Biblioteca da Universidade de Colúmbia em Nova York. As traduçớes feittas modernamente para as mais variadas ínguas săo múltiplas.

O estudo das fontes da obra de Paulo Orósio é tema muito importante. Podemos afirmar sem temor que ele năo é dos quë, nos primórdios do Cristianismo, incompatibilizaram a cultura clássica e a cultura pagă, como Tertuliano, por exemplo. Pelo contrário, a sua valorização da cultura clássica se evidencia quando se verifica o número e a variedade dos autores citados no correr das páginas de sua História. $\mathrm{O}$ autor preferido parece ser Virgnio a quem cita quatorze vezes. Chama-o indistintamente: "poeta", "o maior dos poetas", "Virglio" ou, simplesmente, omite-lhe o nome contentando-se com citar-lhe o texto por julgar que é conhecido de todos. Comélio Tácito é nomeado nove vezes e Suetónio, sete. Outros autores clássicos, tanto historiadores como poetas, citados em menor número de vezes são: Pompeio Trogo, quatro; Justino, duas; Flávio Josefo, duas e Tito Livio, Fanocles, Palefato, Homero ("famoso entre os melhores"), Tirieo, Fábio Pictor, Políbio, Eutrópio e Claudiano, uma vez. De Cornélio Tácito diz: "... narrou com grande exatidão". E, da opiniăo de Eutrópio, se permite discordar: "No ano 864 da fundação da cidade - embora Eutrópio diga que foi no ano de 850 ..."9.

Com referência às fontes cristãs, encontramo-las explicitadas em menor número, embora seu pensamento seja cristão e o objetivo único de sua obra, a defesa do cristianismo. A Bßblia aparece citada explicitamente sete vezes. Isto sem contar, naturalmente, todo o relato da vida do povo judeu antes da vinda do Cristo. $O$ grande escritor Orf́genes é citado apenas duas vezes. Todos estes dados nos falam, de forma clara e explicita, da grande cultura de Paulo Orósio, tanto mais admirável quanto se considera como Santo Agostinho que era "jovem".

$\mathrm{Na}$ leitura da História de Orósio encontramos ainda outros dados que nos ajudam a aprofundar mais o seu apreço pela cultura clássica. No livro 1 cap. 18 , falando da mitologia grega, diz: "O ensino da escola se gravou também em nossa memória ...". Isto nos leva a pensar que Orósio era um romano culto, que freqüentava a escola e recitava os clássicos mais importantes. Palavras que encontramos repetidas várias vezes săo: "professor" e "instruçáo". Assim, por exemplo, referindo-se ao imperador Juliano diz: "... ordenou num Edital que nenhum cristăo fosse professor das artes liberais" e, na vida de Aurélio Alexandre, encontramos: "Sua máe preocupou-se em receber instruçăo :..."10.

As bibliotecas săo objeto de especial cuidado na obra de Paulo Orósio. Sente muito o que significa sua destruiçăo. Tratando das batalhas de César no Egito, dá todo

$9-(1982:$ v. $2,197-8)$.

$10 \div(1982: 239.210$ respectivamente). 
gênero de detalhes do desaparecimento da mais famosa biblioteca da Antigüidade, a de Alexandria: "As chamas ... destrufram quarenta mil livros que estavam nos ediffcios proximos, os quais constitulam um grande testemunho dos estudos e inquietaçoes dos antepassados porque reuniam muitas e ilustres obras de grandes talentos ...". Mais tarde, na época do imperador Cómodo, encontramos a mesma intensidade de sentimentos frente à destruiçăa de outra grande biblioteca: "... no Capitólio caiu um raio, por cuja causa se levantou um incéndio que queimou em rápido movimento aquela famosa biblioteca construida com cuidado e o interesse dos antepassados" 11 .

Parece-nos, assim, poder afirmar que Osório é na Antigüidade Tardia um digno expoente do Mundo Clássico pela valorização que ele faz da cultura romana.

Também é possivel afirmar, até onde chegaram as nossas pesquisas, com relação à sua atitude de historiador frente à doutrina de Clcero sobre a maneira de se escrever história. A primeira lei é a "verdade". Paulo Orósio, embora năo fạça, como ałguns clássicos, solene profissão de veracidade, em parte nenhuma de sua obra se esforça por demonstrar-nos que persegue a verdade como ideal. "Vou colocar-me nas mãos da crfica, embora com a esperança de salvar-me com a ajuda da verdade ..." "E, embora se possa acrescentar, ainda por nossa parte, outras provas deste tipo, igualmente dignas de ser contadas e inquestionáveis pela sua credibilidade ..."12.

No entanto, uma leitura um pouco mais profunda da obra de Paulo Orósio nos leva a constatar que, apesar de suas afirmações, ele não cumpre esta primeira lei da história estabelecida por Clcero: a verdade. A História de Osório é, melhor do que história, uma apologia do Cristianismo. Por isso, tudo está ordenado em função do objetivo primeiro. Não pode ser considerado falta de verdade. É apenas a resposta sincera do autor ao seu objetivo fundamental.

A segunda lei da historiografia clássica é a "brevidade". Esta sim, parece ser cumprida à perfeição pelo nosso autor. É por isso que torna diffcil escolher entre as injmeráveis citações repetidas incansavelmente no decurso de toda a obra. "Resumirei agora brevemente ..." "Vou assinalar o mais brevemente possivel ..."13. "Para que me entreter em muitos detalhes?" "Passo por alto pelas freqëntes derrotas ..., passo por alto pelos tristes sucessos ... passo por alto pelas freqüentes barbáries ..."14.

Outro cânone, cumprindo por Paulo Orósio, é a "ordem". "Dá-me a impressâo de que quanto mais busquei a ordem, com maior desordem eu escrevi estas idéias". "Em vão vou explicar as guerras $\theta$ quedas de tantos reis e reinos se antes náo explico quem foram os reis e quais os reinos ..."15. "Pelo que se refere a Jugurta, por motivos de ordem cronológica ..."

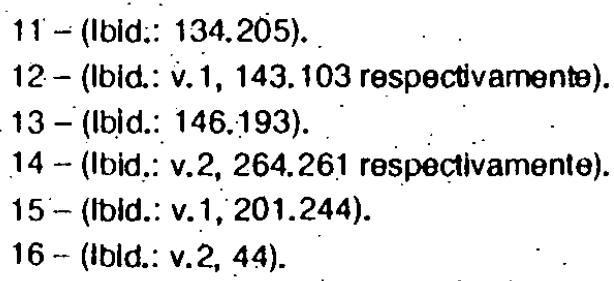


Mais uma lé clássica da história diz respelto à explicitaçăo das causas e resultados. Também aqui, notamos o sentido do cumprimento por parte de Paulo Orósio. "Narrarei, na medida em que eu puder, as desgraças concretas de cada um dos povos,... desde seus começos e de que forma e por que razbes surgiram ${ }^{m 17}$.

O retrato, ou a caracterizaçăo dos individuos, é outra norma năo descuidade na obra do autor. Coloca, por exemplo, especial cuidado no tratamento dado aos imperadores. Assim, falando de Callgula, diz: "... o homem mais malvado de todos os que tinham vivido antes dele ..." No retrato de Nero, escolhe as trintas ainda mais negras: "Continuador e superador até do tio Callgula em todo tpo de vícios e crimes, excedeuse em petulância, paixăo, luxo, avareza e crueldade". Segue, depois, explicitando com fatos reais $\theta$ abundantes as diversas manifestaçбes concretas do anteriormente dito. $A$ figura de Tibério ganha outras palavras $\theta$ expressర̋es: "Tibério dirigiu pessoalmente o Estado com grande $\theta$ serena medida, até o ponto de que a algum dos governadores que the haviam aconselhado que aumentasse os impostos nas províncias, escreveu respondendo que 6 próprio de um bom pastor amar o seu rebanho. $O$ inimigo de Roma $\varepsilon$ tratado duramente: "Viriato, de origem lusitana, $\theta$ pastor e bandoleiro. Aterrorizou na Hispånia a todos os romanos, pithando primeiro os caminhos, assolando depois as províncias. Vencedor, desbaratou e pós em fuga os exércitos de pretores e cônsules"18. Uma das grandes figuras da antigüidade, Alexandre Magno, foi assim descrita por Orósio: "Nestes dias nasceu Alexandre Magno, aquele grande e autêntico abismo de desgraças $\theta$ atroz torvelinho de todo o Oriente". "Sua crueldade para com os parentes năo foi menor do que a loucura manifestada contra os inimigos". "Alexandre nunca se saciava com sangue humano, fosse de inimigos ou de aliados. Sempre tinha sede de sangue novo" 19 .

Outra lei do gênero histórico é a inclusáo de referências geográficas na obra histórica. Esse cånone ocupa lugar de desteque no conjunto da obra de Paulo Orósio. "É necessário, penso, que descreva em primeiro lugar o próprio orbe das terras habitadas pelo gênero humano ..." Afirma.categoricamente que percorreu, na medida das próprias forças, as provincias e ilhas de todo o mundo e, por isso, toda sua obra histórica está repleta de descriçסes de fenóniemos naturais (a terra e suas chuvas, ventos, mares, etc.) ou de catástrofes (terremos, inundaçסes, etc.). ou simplesmente de povos e cidades. O capftulo 2 do livro 1 é a descrição de todo o universo e é o mais longo de toda a obra, com cento e seis versículos.

Há, alnda, mals um ponto em que nos parece poder afirmar que Paulo Orósio é romano clássico. Embora ele se proponha a escrever uma história universal, na verdade o que resulta é uma história do Império Romano ao redor do qual giram, de alguma maneira, todos os outros povos ou impérios. Roma é o centro de gravidade. É por isso que a cronologia se refere sempre à fundaçăo de Roma. Iniclalmente encontramos: "No ano 805 antes da fundaçáo da cidade ..." "No ano 30 antes da fundaçăo de Roma ..."

17 - (Ibld.: v. 1, 102).

18. (Ibid.. v.2. 180.187.176. 19 respectivamente).

19 (Ihid. v. 1. 208.232). 
A partir do livro II, os anos se contam depois da fundaçăo da cidade, ou depois da fundação de Roma. Roma é a cidade por exceléncia, pelo que não tem possibilidade de se confundir com nenhuma outra. A história de Roma é também a mais extensamente tratada e com maior carinho e riqueza de detalhes. "Teremos que nos deter, antes de mais nada, na história dos romanos ..."20. Diz no livro I e no inf́cio do $V$ volta a insistir: "Os fatos romanos nos quais se centra o nosso tema săo tăo grandes que, com razăo, ficam de lado os outros"21. Dos sete livros escritos somente o primeiro năo trata da história de Roma e sim dos outros povos anteriores na ordem cronológica. A fundaçăo de Roma encontra-se logo no início do livro II.

Tratamos de encontrar, até agora, em Paulo Orósio algumas reminiscências do clássico romano. Vejamos, agora, se há nele alguma mudança, algo que o diferencie dos autores e pensadores anteriores ao Império Romano; se foi afetado, de alguma forma, pelo momento histórico em que viveu, decisivo na história, do "saque de Roma" por Alarico. $\mathrm{Na}$ visăo histórica contida nos Sete Livros de História contra os Pagăos, qual a versão do mundo romano que nos é transmitida?

Já no prólogo, o autor confessa, como profissăo de fé, os pontos de diferença entre ele e os outros historiadores: "Tanto entre os gregos como entre os latinos, quase todos os escritores que propagaram com suas palavras as açőes de reis e povos, começaram suas obras com Nino, filho de Belo, rei dos assirios ... Eu decidi contar o começo das desgraças humanas partindo do primeiro pecado humano. Desde Adão, 0 primeiro dos homens, até o rei Nino, "o Grande", como é chamado, época em que nasceu Abrão, passaram 3184 anos, anos que foram omitidos ou ignorados por todos os historiadores". Divide, assim, Paulo Orósio os perlodos históricos em três etapas: $1^{\text {a) }}$ ) de Adão a nilo, que é contemporâneo de Abrão; $2^{a}$ ) de Nilo até César Augusto - o momento do nascimento de Cristo e $3^{\mathrm{a}}$ ) de César Augusto até seus dias.

O motivo pelo qual começa a história por Adão parece evidente: trata de encontrar o verdadeiro infcio da história universal, e, também, de descobrir na desobediência do primeiro homem à lei divina a chave que abre a fonte de todas as misérias e sofrimentos humanos. A inter-relação pecado-castigo é para Paulo Orósio a linha da evolução histórica. Assim concebe "... a história como uma unidade orgânica submetida a uma lei interpretativa: a partir do pecado de Adăo o homem quebra seu pacto com Deus e todas as ações humanas posteriores, até a vinda de Cristo, estarăo marcadas por essa separaçăo entre Deus e o homem"23.

Vemos, também, que nessa divisão cronológica estăo associados Nino a Abraão e César ao nascimento de Cristo. Essa relaçáo entre os personagens da história universal e a história de Cristo é outra das formas da evoluçáo histórica do pensamento de Paulo Orósio. Na história de Roma o momento culminante será a época de Augusto, a "Pax Romana". Para Paulo Orósio, isto náo é devido somente às virtudes dos cidadăos romanos, nem sequer à própria obra de Augusto. É a obra da Providéncia de Deus, que

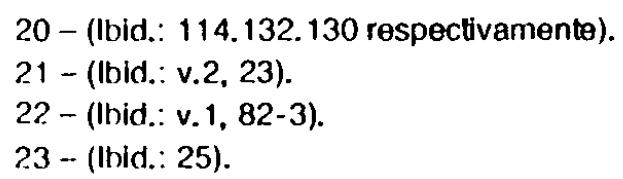


prepara o caminho para o verdadeiro Reino Universal e etemo cristăo. Reino que é feito dentro dos próprios caminhos do Império Romano. O aparecimento de Cristo trará o inicio de novos tempos. O mito da Roma eterna pagå encontrará a sua verdadeira continuidade no Império Universal cristão. Roma năo morre, continua na Roma cristã. Assim, Paulo Orósio está interpretando a clássica profecia de Daniel sobre os Impérios: "A culminaçăo dos tempos virá com a dissoluçăo do último dos impérios e a aparicão de Oriente ao Ocidente, do Norte ao Sul e ao redor de todo o Oceano, ele mesmo fechou as portas do templo de Jano ... Naquela época, ou seja, no ano em que César conseguiu estabelecer por disposição de Deus, uma paz autêntica e durável, nasce o Cristo. Essa paz teve por objetivo favorecer a vinda de Cristo, em cujo nascimento os anjos fizeram os homens ouvir seu canto de júbilo: "Gloria a Deus nas alturas e paz na terra aos homens de boa vontade". Nesse mesmo ano em que o próprio Deus se dignou mostrar-se e ser como homem, César, a quem Deus tinha predestinado para tão grandes mistérios, ordenou pela primeira vez que se fizesse um recenseamento de todas e cada uma das provincias e que fossem recenseadas todas as pessoas. Nessa época, pois, nasceu Cristo e imediatamente depois de nascer, foi inscrito no recenseamento romano. Essa declaraçăo consagrou César como senhor universal e os romanos como donos do mundo; com essa declaração, Cristo quer dar-se a conhecer como homem e fazer-se contar entre eles. Tal privilégio, desde a criação do mundo, não tinha sido concebido nem ao primeiro babilónico, nem ao macedónico, para não citar outros menores ... e não há dúvida de que foi Cristo quem depois de fazer crescer esta cidade (Roma) e defendê-la levou-a ao ponto mais alto de seu poder. Isso foi feito assim porque Ele quis ser cidadão romano, em virtude de sua inscrição no recenseamento romano. Dado que chegamos ao momento em que Cristo iluminou este mundo com sua chegada e conseguiu para César um templo de paz, eu posso pór fim a este livro ..."24.

Foi citado anteriormente no próprio texto de Paulo Orósio o império babilónico, o macedónico e outros menores. Vale a pena neste ponto também, explicitar um pouco mais e ler as próprias palavras do autor. Torna-se igualamente necessário, visto que já noss tínhamos referido em outro momento à profecia de Daniel. Paulo Orósio abre o livro II com a explicação da teoria dos "Quatro Impérios" e sua aplicação ao Romano. No início do livro VII, volta ao mesmo tema, explicitando-o ainda mais.

Os autores antigos consideraram os quatro impérios como o assírio, o medo-persa, o macedónio e o romano. Paulo Orósio introduz algumas variaçठes e os considera assim: o babilónico, o macedónico, o cartaginês e o romano. Eis em sintese, o pensamento de Paulo Orósio nesta teoria dos quatro impérios: Roma recolhe a herança de Babilónia $\theta$, depois de cruéis e terriveis confrontos com os impérios que ele considera intermediários: o macedónico e o cartaginês, consegue unificar todo o poder numa só pessoa, César Augusto, em cuja época o nascimento de Cristo ínicia uma nova era. Depois de Cristo, a história se reduz a uma progressiva identificaçáo entre o Império

24 -(1982: v.2, 159-61). 
Romano e o Cristianismo (Neste ponto será bom lembrar, entre os retratos de diversas personagens, o de Alexantre Magno, o grande artfice do Império Macedónico). As palavras de Paulo Orósio explicitando esta idéia estáo esparsas por toda a obra. Escolho, apenas, umas linhas do livro II, cap. 3, ver. 5-7.

Considero oportuno recordar ... que só Deus é quem dispôs a ordem dos tempos em favor, num momento dos babilónios, e finalmente, dos romanos e, que devemos à sua misericórdia, o fato de que existamos. Com efeito, eis que as origens de Roma e de Babilônia foram semelhantes, semelhantes em grandeza, semelhantes em duração, semelhantes em seus bens e seus males, no entanto não foi semelhante seu fim nem seu desaparecimento: Babilónia perdeu seu império, Roma o mantém, aquela foi órã do seu rei, e esta se mantém firma com a vida do seu imperador. E isto por que? ... graças à religião cristã"25.

Um aspecto que não passa despercebido na leitura de Paulo Orósio é a valorização que é dada aos godos, ou visogodos, dentro do quadro geral dos bárbaros. Podemos acompanhar sua história na obra do autor: "Os hunos, excitados agora por uma repentina loucura, levantaram-se contra os godos e, depois de acossá-los, os expulsaram dos seus antigos lares. Os godos, depois de atravessar o Danúbio, fugindo, foram recebidos por Valente ..." "Alarico e todo o povo godo pediam com hulmides súplicas uma paz digna e uns lugares para viver". (Teodósio) "concluiu um tratado com o rei godo Atanarico. Porém Atanarico morreu e todos os povos godos, depois da morte do seu rei, se entregaram ao poder romano ao experimentar o valor e a benignidade de Teodosio". "Morto o Augusto Valentiniano, foi nomeado ousamente um usurpador a quem, depois, impōem o nome de imperador: um homem bárbaro, porém cheio de coragem, de bom sentido, de força, de audácia, de poder. Reuniu muitas e invictas tropas das guarniçס̋es romanas e das tropas auxiliares bárbaras". "... depois os bárbaros, desprezando as armas se dedicaram à agricultura e respeitam aos romanos pouco menos do que como aliados e amigos ${ }^{m 26}$.

O próprio "saque de Roma" de Alarico, de 410, de memória inesqueclvel para os romanos, não parece ser tão trágico na visão de Paulo Orósio: "Apresenta-se Alarico que acredita, aterroriza e invade a temerosa Roma, embora ele tivesse dado ordem aos seus, com antecedência, que náo incomodassem a todos aqueles que se refugiassem em lugares sagrados e que, na medida do possivel, se abstivessem de derramar sangue, entregando-se, apenas, ao botim"

Alarico deu ordem para que os vasos sagrados fossem levados até a baslica do Apóstolo". "Três dias depois de ter entrado na cidade, foram-se embora espontaneamente, provocando o incêndio de alguns ediffcios. Porém nunca este incéndio foi tăo grande como aquele do ano 700 da fundaçáo da cidade"27.

25 - (bid.: v.1, 103).

26 - (Ibid.: v. 2,246.266.249.253.274).

27 - (Ibid.: 268-9). 
Năo há comparaçăo possivel entre este quadro pintado por Orósio relativo a Alarico $\theta$ a descriçåo do assalto a Roma feito por gauleses: "Os gauleses penetram na cidade sem defesa, matam os senadores, queimam as casas, ... provocam fome, peste, desespero e medo aos desafortunados sobreviventes $\theta$, posteriormente, os submetem e os obrigam a pagar um resgate por eles mesmos. Quando os gauleses foram embora, o horror enchia os ânimos, ... e os romanos pensaram $\theta$ até tentaram trocar de lugar, fundar outra fortaleza $\theta$ até chamar-se com outrro nome ${ }^{\text {n28. }}$.

Por que estes quadros valorizando as virtudes dos godos, que são bárbaros e năo romanos? Como explicar as diferenças que sentimos da invasăo de Roma pelos gauleses e pelos godos de Alarico? Em primeiro lugar pode-se interpretar como uma resposta aos interrogantes colocados, tanto por pagáos como por cristăos, diante do "saque de Roma" que, apesar das apreciaçőes de Paulo Orósio, foi sempre visto na história como a queda ou fim de Roma ou, ao menos, a queda de um mito. Os Sete Livros da História contra os Pagăos. responderăo que Roma sofreu mais em outras épocas, que os godos năo foram tăo terriveis como os gauleses, que respeitaram as pessoas, enfim, que Roma continuava viva, e que, se os outros Impérios anteriores a ela foram dominados e vencidos por ela, ela, Roma, continua sendo Roma. Esta resposta seria válida tanto para cristãos como para pagãos, pois todos podem entender, cada um ao seu modo, a perenidade de Roma.

Paulo Orósio quis dar uma resposta, ainda mais direta, aos cristãos e julgamos encontrá-la poucas linhas após a descrição do "saque de Roma" propriamente dito: "... romanos e bárbaros, unidos num só coro, cantam publicamente um hino a Deus. $O$ som da trombeta da salvaçăo ecoa em todos os cantos da cidade"29.

Paulo Orósio contempla já uma antevisão de uma nova era, do Império Universal Cristão, de que fala a profecia de Daniel. Os bárbaros cristianizados são parte integrante da nova Cidade Eterna. $O$ autor capta toda a força histórica do momento que está vivendo. Sabe que a Providência Divina, Deus, colocou o Império Romano, com toda a sua grandeza e esplendor, como o caminho a ser seguido para se chegar ao verdadeiro Império, querido por Deus, desde o ińcio dos tempos. Roma toi a primeira protagonista, a imprescindfvel, desta nova era. O mito da Roma Eterna tem, para Paulo Orósio, uma personagem que o sustenta e perpetua, a Providéncia, e está composto este mito com diversas peças: săo as sobrevivências e as mudanças que caracterizam o acontecer histórico do ińcio do século $\mathrm{V}$.

28 - (Ibid.: v. 1, 186-7)

29 - (It)id.: v. 2, 268). 
INDICAÇÄO BIBLIOGRÁFICA

OBRA GERAL

ANDRE, J. M. La historia en Roma. Buenos Aires, Siglo XXI, 1975.

TEXTOS

AGUSTIN, San. Obras. Madrid, BAC, 1953. v.11.

BíBLIA SAGRADA. Petrópolis, Vozes, 1982.

JERÓNIMO, San. Cartas. Madrid, BAC, 1962. v.2.

OROSIO. Historias. Madrid, Gredos, 1982. 2 v. 